食物による閉塞により腸捻転をきたした 1 例

東邦大学第 2 外科

池田正視島田長人柴忠明

10年前に幽門側胃切除術を受けた29歳の男性. 夕食のおでんでシラタキコンニャクの 球を $2 つ$ 続けて食へ，翌日の昼より腹痛。嘔気，澏吐が出現し来院した。腹部診察，単 純撮影, CT scan 所見より，絞扼性イレウスと診断し同日開腹術を施行した. 開腹所見 はシラタキコンニャク塊が回盲弁より口側約 $60 \mathrm{~cm}$ の回腸を閉塞し，口側の腸管が拡張 して捻転し，食事に起因する絞扼性イレウスであった。食物によるイレウスの多くは緩 徐な発症経過をたどり術前に癒着性イレウスの診断にて開腹となる症例がほとんどであ るが，今回のように捻転絞扼することも念頭に入れるべきであると考える．本症の診断 にCT scan は有用であった。また本症を回避するには，胃切除術の再建法を充分配慮す べきで，胃切除後患者に対しては食事指導を徹底することが大切と考えられた。

卖引用語：シラタキコンニャク，腸捻転，CT scan

\section{緒 言}

日常，撖取している食飰が原因となり発症するイレ ウスは比較的緩徐な経過と症状を呈すると言われてい る. 胃切除後症例では食事摄取より発症までの期間が 短い急性型が多いが，腹部膨隆，圧痛，嘔気，嘔吐を 訴え，疮着性イレウスと診断され開腹に至る症例がほ とんどである1)-31.われわれはシラタキコンニャクが 原因となり発症し，攝取後より急激な経過を経て捻転 による紋扼性イレウス状態にまで宿った胃切除後食物 によるイレウス症例を経験したので，1956年以降の本 邦報告34例も含め報告する。

\section{症 例}

患者：29歳, 男性.

主訴: 腹痛, 嘔吐.

既往歴：10年前に十二指腸潰晹による幽門狭窄のた 内胃切除術施行。

家族歴：特記すべきことなし。

現病歴：1991年 9 月27日夕食のおでんでシラタキコ ンニャクの球を 2 つ続けて摄取した. 28日昼頃より突 然腹痛が出現し，その後哣気，螵吐が出現した。腹痛 は開歇的であったが軽快しないため夕方近医受診し， イレウスの診断にて当院紹介され，同日救急外来受診 し，入院となった。

入院時現症：体格中等度，栄養良好. 眼球・眼瞼結

1996年 1月22日受付 1996 年10月 8 日採用
膜に異常所見なし．血压110/72mmHg，脈拍80回/分， 体温37.9度. 胸部に異常所見なし，腹部は平坦だが臍 の右側に強い圧痛と筋注防御を認めた．腸雑音は微弱 で金属音は聴取されなかった，異常腫瘤，肝脾腎は触 知せず．上腹部正中に手術による疫痕を認めた．排ガ ス，排便はなかった，四肢に異常所見はなく，表在り ンパ節の腫脹も認めなかった。

血液検查：白血球が $19,000 / \mathrm{mm}^{3}$ と增加を呈し, Hct は54.8\%であった. GOT, GPT, AMY, BUN, CREATININEなどは正常であった（表 1).

$\mathbf{X}$ 線検査：腹部単純撮影は, 臥位で拡張した小腸 loop 像, 立位で鏡面像を認めたが, 腸管内ガス像は目 立たなかった（図 1)。

腹部 CT 検査：軽度の腹水と小腸の著明な拡張像を

表 1 入院時血液生化学的検查所見

\begin{tabular}{lc|lc}
\hline WBC & $19,000 / \mathrm{mm}^{3}$ & T-bil & $0.9 \mathrm{mg} / \mathrm{dl}$ \\
$\mathrm{RBC}$ & $583 \times 10^{4} / \mathrm{mm}^{3}$ & GOT & $14 \mathrm{IU} / \mathrm{L}$ \\
$\mathrm{Hgb}$ & $18.4 \mathrm{~g} / \mathrm{dl}$ & GPT & $4 \mathrm{IU} / \mathrm{L}$ \\
$\mathrm{Hct}$ & $54.8 \%$ & LDH & $320 \mathrm{IU} / \mathrm{L}$ \\
$\mathrm{PLT}$ & $31.9 \times 10 / \mathrm{mm}^{3}$ & ALP & $111 \mathrm{IU} / \mathrm{L}$ \\
$\mathrm{CRP}$ & $0.1 \mathrm{mg} / \mathrm{dl}$ & AMY & $34 \mathrm{IU} / \mathrm{L}$ \\
$\mathrm{Na}$ & $139 \mathrm{mM}$ & $\mathrm{P}-\mathrm{AMY}$ & $11 \mathrm{IU} / \mathrm{L}$ \\
$\mathrm{K}$ & $4.6 \mathrm{mM}$ & $\mathrm{UN}$ & $14 \mathrm{mg} / \mathrm{dl}$ \\
$\mathrm{Cl}$ & $95 \mathrm{mM}$ & $\mathrm{Cr}$ & $1.1 \mathrm{mg} / \mathrm{dl}$ \\
$\mathrm{Tp}$ & $5.8 \mathrm{~g} / \mathrm{dl}$ & $\mathrm{CPK}$ & $88 \mathrm{IU} / \mathrm{L}$ \\
$\mathrm{Alb}$ & $3.5 \mathrm{~g} / \mathrm{dl}$ & & \\
\hline
\end{tabular}




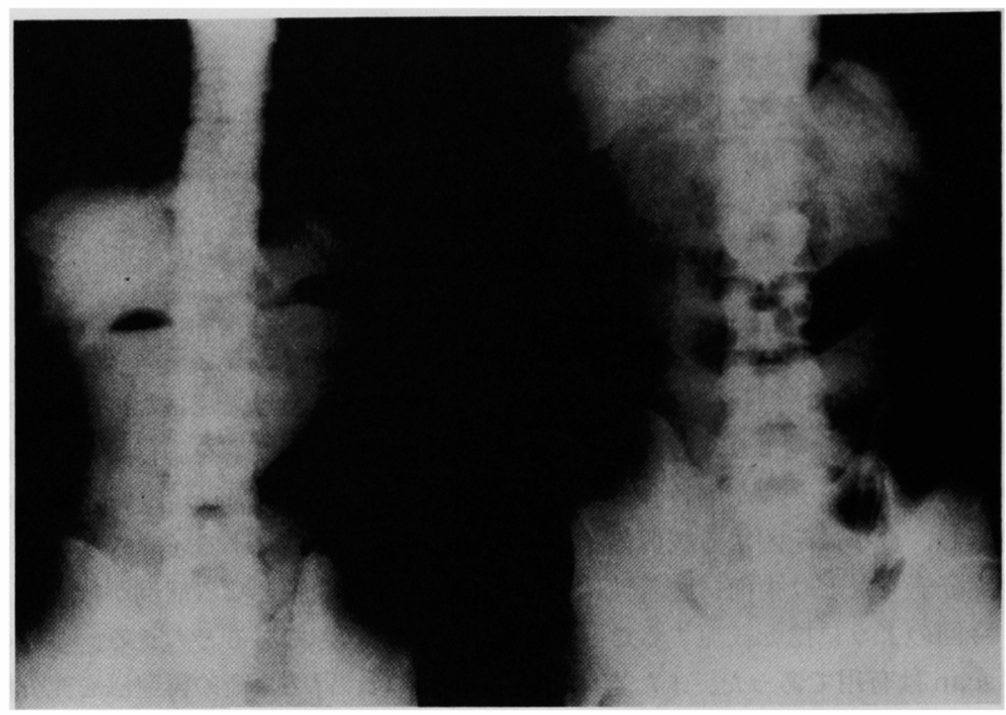

図 1 腹部単純 $\mathbf{X}$ 線所見：小腸にガス像, 立位で鏡面像を認める.

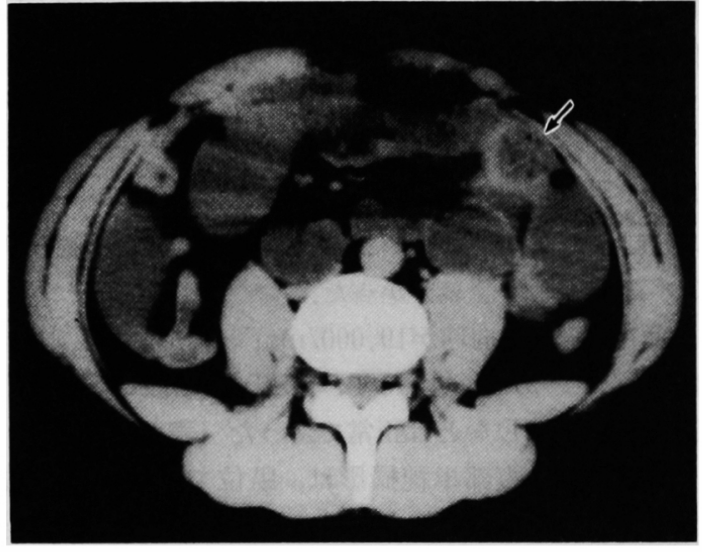

図 2 腹部 CT scan 所見：小腸の著明な拡張と腸管 内異物 $(\rightarrow)$ を認める.

認めたが, 腸管内容液に比べガスの貯留は軽度であっ た。腸管内にシラタキ塊と思われる内容物を認めた(図 2 ).

手術所見：皎扼性イレウスを疑い，9月28日全身麻 醉下に上腹部正中切開で開腹した. 腹腔内に淡血性腹 水の貯留を認めた。 小腸は著明に拡張し, 一部で小腸 漿膜および腸間膜に浮腫や点状出血を認め, 絞扼性イ

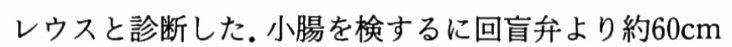
口側の回腸に直径約 $5 \mathrm{~cm}$ の腫瘤が触知され, 口側腸管 が著明に拡張していた。腫瘤の口側端で約 $50 \mathrm{~cm}$ の回 腸が, 時計方向に180度捻転していた. 用手にて反時計

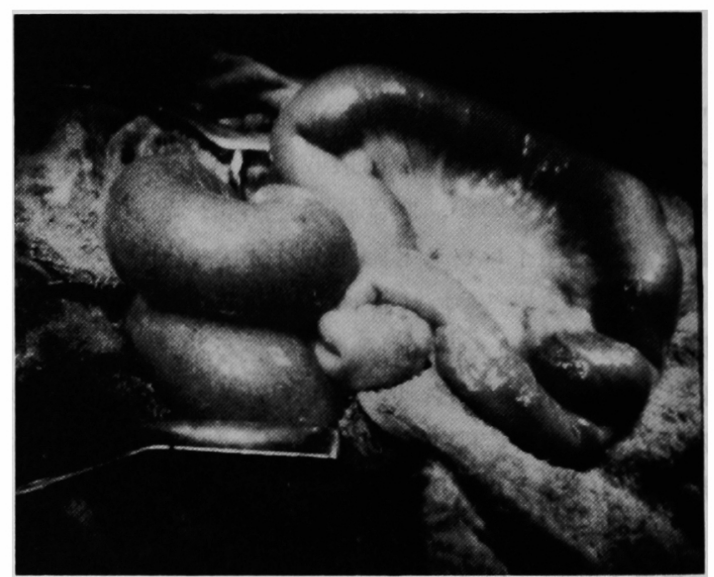

図 3 術中写真所見 : 小腸および腸間膜に浮腫, 点状 出血を認め, 口側腸管の著明な拡張を認めた。

方向に 180 度回転し捻転を解除した（図 3 ). 回腸内の 腫瘤は触診上食物性異物と考え, 回盲部への誘導を試 みたが困難なため, 拡張のない回腸にて横切開を加え 異物を摘出した. 切開部を修復後, 腹壁を 2 層縫合に て閉腹した。術中には上腹部の癒着が強く胃切除後の 再建部位は検索しなかった。

摘出標本 : $5.0 \times 5.0 \mathrm{~cm}$ のシラタキ塊であった（図 $4)$.

術後経過：術後第 5 病日より食事摄取開始したが, 第10病日に術後イレウスを併発した。保存的療法にて 


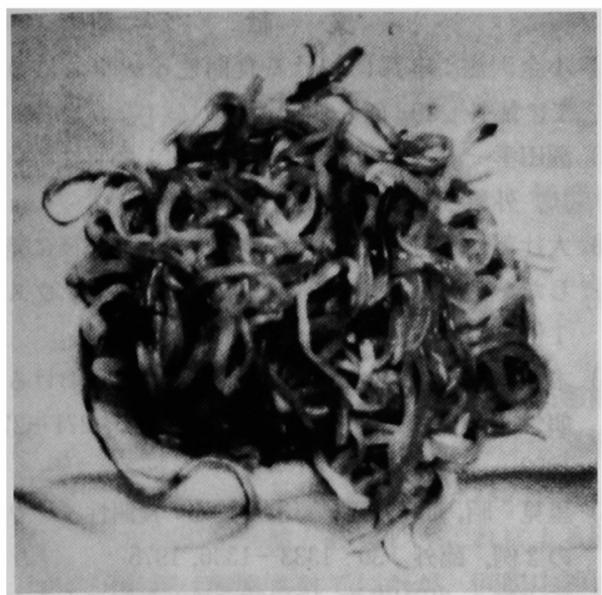

図 4 摘出標本 : 直径 $5 \times 5 \mathrm{~cm}$ のシラタキ塊.

軽快し第39病日に退院した。なお術後に施行した経口 消化管透視にて, 胃切除後の再建法は Billroth II 法で あった。

\section{考 察}

食物によるイレウスの原因となる食物は胃切除後症 例では柿の $35 \%$ に次ぎシラタキが約 $30 \%$ を占めている (表 2). しかし, 胃切除後症例に限定しない場合は小 金沢1にによると柿が $63.9 \%$ と圧倒的に多く，シラタキ は稀となる，胃切除患者は胃による貯留，混和機能が ない上，幽門も欠如するため未消化のシラタキが小腸 へ侵入し易いためと考える。

食物塊の大きさについてみると本邦報告例の平均長

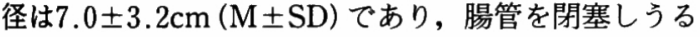
食物塊はかなり大きいものであった。今回のシラタキ 塊も $5 \times 5 \mathrm{~cm}$ であり， $1 \mathrm{~cm}$ スライスのCT scanにて腸 管内に在存することがほほ確認しえた. CT scan は本 症の疑われた症例に確定診断を下す上で, 食物塊の成 分にも関係するが，施行する意義のある検査と考えら れた.

食物による閉塞部位に関しては，本邦報告例では約 $70 \%$ が回腸であった(表 3 )。この事は回腸下部が腸管 の内腔が比較的狭く，腸蠕動も弱いためと考えられて いる ${ }^{244)}$. 今回の症例も一塊となってシラタキが空腸に 進入し，最終的に回腸下部に停留したと考えられ，閉 塞部に狭窄を来す様な疻着は認めなかった。

胃切除術式による本症の頻度は, 本症例も含め約 65\%が Billroth II 法であった (表 4 )．これは Billroth II 法がI 法に比しその吻合径が大きくなるケースが多 く4), 位置的にも食物がほほ直線的に輸出脚へ原形の
表 2 食物によるイレウス（胃切除術後）の閉塞物

\begin{tabular}{lr} 
1) 柿 & $12(35.3 \%)$ \\
$2 ）$ シラタキ & $10(29.4 \%)$ \\
$3 ）$ ゴボウ & $2(5.9 \%)$ \\
$4 ）$ ウリ & $1(2.9 \%)$ \\
コンフ & $1(2.9 \%)$ \\
スルメ & $1(2.9 \%)$ \\
タクアン & $1(2.9 \%)$ \\
トウモロコシ & $1(2.9 \%)$ \\
野莱 & $1(2.9 \%)$ \\
ラーメン & $1(2.9 \%)$ \\
不 明 & $3(8.8 \%)$ \\
\hline \multicolumn{2}{c}{$(1956-1993$ 本邦報告全34症例) }
\end{tabular}

表 3 食物によるイレウス（胃切除後）の閉塞部位

\begin{tabular}{lr}
\hline 十二指腸 & 2 例 $(5.9 \%)$ \\
空 腸 & 8 例 $(23.5 \%)$ \\
回 腸 & 25 例 $(73.5 \%)$ \\
不 明 & 2 例( $5.9 \%)$ \\
\hline \multicolumn{2}{c}{$(1956-1993$ 本邦報告全34症例) }
\end{tabular}

表 4 食物によるイレウス症例の既往胃切除術式

\begin{tabular}{llr}
\hline Billroth & I 法 & 12例(35.3\%) \\
Billroth & II 法 & 22例(64.7\%) \\
\hline & \multicolumn{3}{c}{$(1956-1993$ 本邦報告全34症例) }
\end{tabular}

まま落下するためと考えられる。しかし Billroth II 法 に限らず，このような食物の通過状態が生じる再建て あれば問題であると考えている。

本症は本来, 単純性イレウスであり, 比較的緩徐な 経過をたどり，術前の質的診断は非常に困難と言われ ている2(3)5)．われわれの症例は術前の問診より食物に よるイレウスが強く疑われ，CT scan 所見でほ沽確定 診断に至ったが，本症のなかではかなり急激な発症経 過をたどり，拡張腸管が捻転し絞扼性イレウスに陥つ た稀な症例であった，急激な発症経過を呈する症例は あるが，開腹時に腸捻転を呈した絞扼性イレウスと診 断した報告はない.腸管は360度捻転することにより血 行障害が生ずるとされているが, 今回の症例は180度の 捻転で血行障害が併発し絞扼性イレウスに陥った。こ のことは捻転した腸管が，正常腸管ではなく，食物に よる閉塞で著明に拡張しすでに循環障害が存在してい た腸管および腸間膜であったためと考えている，本症 が疑われた症例は穿孔性腹膜炎を呈した報告6)7もあ り, 症状が増悪する場合は躊踷することなく手術に踏 み切らないと重症化することが示唆された。本症例は 
食物によるイレウスと考えたが, 腹部診察, 単純撮影 とCT scan 所見より絞拒性イレウスも疑い緊急手術 を施行したため小腸壊死, 部分切除を回避し得たと考 えている。つまり逆に絞抑性イレウスだからと言って 本症を除外することはできない.

\section{結語}

胃切除後患者でシラタキコンニャクを摄取し絞抳性 イレウスを発症した 1 症例を報告し, 若干の文献的考 察を加え検討した。.今回のイレウスは胃切除時の再建 法に起因するところが大きいと考えられた，近年，胃 全摘術症例も増加しており, 胃切除後の再建は, 充分 に考虑されるへき問題と考えられた。しかし，現在す でに胃切除をうけた患者に対しては本症併発を防止す る上で充分な食事指導を徹底させることが必須であ る.また本症の術前診断は依然として発症前の食事摄 取に関する問診に頼るのが現実だが，CT scan はその 診断に有用な侵襲の少ない検査であると考えた。
文献

1）小金沢滋：本邦における食眀性イレウスについ て. 臨外 29:61-70, 1968

2）瀬田孝一, 飯島 仁, 小野雄司他：食餌性イレウ ス. 外科 $39: 473-478,1977$

3）大辻英吾, 获岡範一, 辻本洋行他：胃切除後に発症 したシラタキコンニャクによる食餌性イレウスの 1 例. 臨外 $54: 155-158,1993$

4）木下 平, 山口晃弘, 磯谷正敏他：当院における食 触性イレウス14例の検討. 臨外 $37 ： 271-275$, 1982

5）里見 昭, 㚼尾正彦, 徳永 剛他：食眲性イレウス の 2 例. 臨外 $30: 1333-1336,1975$

6）広正修一, 坂本孝雄, 山口敏之他：鏡餅による小腸 穿孔の 1 例. 最新医 $44: 2566-2568,1989$

7）岩淵 悟, 川上 稔, 小池加保児他：穿孔性腹膜炎 を伴ったモチによる食餌性イレウスの 1 症例. 外 科 $54: 430-432,1992$

\title{
A CASE OF VOLVULUS BY FOODS
}

\author{
Masami IKEDA, Nagato SHIMADA and Tadaaki SHIBA \\ Second Department of Surgery, Toho University of Medicine
}

A 29-year-old male was admitted to the hospital because of an abdominal pain, nausea and vomiting. There was a previous history of undergoing a distal gastrectomy for gastric ulcer ten years prior. On the day before admission he ate two balls of Shirataki Konnyaku in Japanese Oden for dinner. A diagnosis of ileus by strangulation was made after abdominal examination, radiographic evaluation and CT scan. A laparotomy was performed and an obstruction of the ileum, $60 \mathrm{~cm}$ from the Bauhin Valve was revealed. The impediment was a mass of Konnyaku. The oral portion of the ileum was significantly dilated and twisted. Most cases of intestinal obstruction with foods have a slow and mild onset of symptoms and undergo laparotomy with a diagnosis of adhesional ileus. But we should also entertain that the disease can present with strangulation ileus with a rapid and severe onset of symptoms as this case suggested. The use of CT scan is extremely valuable in the differential diagnosis. In order to avoid ileus with foods after gastrectomy, we emphasize the importance of selecting reconstruction method for gastrectomy after much thought and of giving the exhausive dietary education to postgastrectomy patients. And it goes without saying that we should recognize the different symptoms by ileus types. 